\title{
Safety Climate and Use of Personal Protective Equipment and Safety Medical Devices among Home Care and Hospice Nurses
}

\author{
Jack K. LEISS ${ }^{1}$ \\ ${ }^{1}$ Cedar Grove Institute for Sustainable Communities, USA \\ Received March 27, 2014 and accepted June 25, 2014 \\ Published online in J-STAGE July 24, 2014
}

\begin{abstract}
Use of personal protective equipment (PPE) and safety medical devices is mandated for healthcare workers to reduce the risk of infection with human immunodeficiency virus (HIV), hepatitis B virus (HBV), and hepatitis C virus (HCV) from exposure to patients' blood. Research has shown that a strong safety climate may promote increased use of PPE. Therefore, the objective of this study was to examine the association between safety climate and use of PPE among homecare/ hospice nurses in North Carolina. To this end, a mail survey was conducted in 2006. The response rate, adjusted on the assumption that the proportion of eligible nurses from among those who did not return the questionnaire or could not be contacted was similar to the proportion among those who did return the questionnaire, was $69 \%$ ( $n=833$ eligibles). The percentage of nurses who used the specified PPE was two to three times greater among nurses who had a strong safety climate. Safety climate was only weakly associated with using safety devices. These results suggest that improving safety climate may be a powerful tool for increasing use of PPE.
\end{abstract}

Key words: Blood exposure, Epidemiology, Home care, Needlestick and sharps injuries, Nurse, Safety climate, Survey, Risk

\section{Introduction}

Use of personal protective equipment (PPE) and safetyengineered medical devices (safety devices) is mandated by the Occupational Safety and Health Administration (OSHA) for healthcare workers who may be exposed to patients' blood ${ }^{1)}$, the purpose of which is to prevent infection with human immunodeficiency virus (HIV), hepatitis $\mathrm{B}$ virus (HBV), and hepatitis $\mathrm{C}$ virus $(\mathrm{HCV})^{2)}$. The responsibility for providing the PPE and safety devices and for ensuring that healthcare workers use them in

*To whom correspondence should be addressed. E-mail: jack1@mcmoss.org.

(C)2014 National Institute of Occupational Safety and Health appropriate situations rests with the employer. However, because the patient's home is not subject to the control of the home healthcare/hospice agency, employers of nurses who provide care in the patient's home are exempt from the requirement to ensure that the nurses use PPE and safety devices in this setting ${ }^{3)}$. Perhaps in part because of this arrangement, home care and hospice nurses remain at high risk for HIV, HBV, and HCV infection from exposure to patients' blood ${ }^{4-7)}$.

Safety climate is defined as employees' shared perceptions regarding safety within their work organization ${ }^{8)}$. It has been associated with use of PPE and safety devices in a variety of work settings ${ }^{9,10)}$. However, the association of safety climate with PPE and safety device use among nurses who provide care in patients' homes has, to our knowledge, not been examined in any previous study. This 
question is important because of the high risk of infection these nurses face, the absence of employer responsibility for enforcing use of PPE and safety devices in home care/ hospice, and the considerable difference between the work and working conditions of home care/hospice nurses and hospital-based nurses ${ }^{11-14)}$. Therefore, the purpose of the present study is to report on this association among home care and hospice nurses in North Carolina, a largely rural state. Furthermore, this paper builds on previous studies of this population, which found that use of PPE varied according to whether the nurses did or did not have to rush during patient visits and did or did not often visit homes in which selected adverse conditions were present ${ }^{15}$.

\section{Subjects and Methods}

The North Carolina Study of Home Care and Hospice Nurses was a mail survey, conducted in 2006, of registered nurses listed in the licensing database of the North Carolina Board of Nursing as working in home care or hospice in non-administrative positions. The questionnaire can be obtained from the author upon request. SAS 9.2 (SAS Institute, Cary, NC, USA) was used to calculate percentages, ratios, and confidence intervals. Complete details of the study design have been published previously ${ }^{4}$. This study was approved by the Institutional Review Board of Weber State University.

\section{Safety climate}

Items that are applicable to home-care nursing (as opposed to hospital-based nursing) were selected from Gershon et al's ${ }^{16)}$ safety climate scale. The eight items, which cover a broad range of subcategories, include support for safety programs, senior management support for safety, communication and feedback about safety, and training and education. The eight items were as follows:

1. The protection of workers from occupational blood exposures is a high priority with management.

2. Reporting blood exposures helps management protect nurses from future blood exposures.

3. Employees, supervisors, and managers all work together to ensure the safest possible working conditions.

4. Employees are encouraged by management to make suggestions for improving worker safety.

5. My supervisor often discusses safe work practices with me.

6. When a new device is introduced, there are procedures in place to ensure I've been correctly trained to use the new device.

7. Supervisors correct unsafe work practices.

8. Employees are taught to be aware of and to recognize potential health hazards at work.

Response options were numbered 1 (labeled "strongly disagree") to 5 (labeled "strongly agree"). These eight items were highly correlated (Cronbach alpha $=0.94)$ and were combined into a dichotomous composite measure (equivalent to a median split) indicating a strong (combined score $>3$ ) or weak $(\leq 3)$ safety climate. Thus, a weak safety climate was defined as one in which the nurses perceived little support for programs designed to ensure their safety, little support from senior management for their safety, poor communication and feedback about their safety, and/or insufficient training and education regarding their safety.

\section{Personal protective equipment}

Use of PPE was measured by posing patient care scenarios in which use of the equipment was indicated to prevent blood exposure. The form of the question was, "The last time you..." The scenarios were (1) irrigated a deep wound (regarding wearing safety goggles), (2) provided ostomy care (regarding wearing a fluid-impermeable apron), and (3) cleaned up large amounts of bloody diarrhea or other bloody body fluid (regarding wearing a surgical mask with eye protection). Nurses could indicate that they always used the equipment when performing that procedure, or they could indicate a reason for not using the equipment on the specified occasion. Additional analyses of these data were presented previously ${ }^{15)}$.

\section{Having to rush}

Nurses were asked whether they would agree with the statement, "I always have enough time during a home visit so that I don't have to rush." Responses were indicated on a 5-point scale ranging from "strongly disagree" to "strongly agree." In order to be consistent with previous analyses, this variable was dichotomized as nurses reporting the two higher agreement values (equivalent to "agree" and "strongly agree") vs. those reporting the lower three values (equivalent to "neutral", "disagree," and "strongly disagree"). Additional analyses of these data were presented earlier ${ }^{11)}$.

\section{Adverse conditions in the home}

Characteristics of homes visited was assessed by four items that asked how often the nurse visited homes with unrestrained pets; unsupervised, unruly children; poor 
Table 1. Percent of nurses who always use selected items of PPE when performing the indicated procedure, by procedure and level of safety climate, North Carolina, 2006

\begin{tabular}{lrrrr}
\hline \multicolumn{1}{c}{ Procedure and level of safety climate } & $\mathrm{n}$ & $\%$ & Ratio* & 95\% CI of ratio \\
\hline Use safety goggles when irrigating a deep wound & & & & \\
$\quad$ Strong safety climate & 232 & 44.8 & & \\
$\quad$ Weak safety climate & 15 & 15.2 & 3.0 & $1.8-4.8$ \\
Use fluid-impermeable apron when providing ostomy care & & & & \\
$\quad$ Strong safety climate & 121 & 21.4 & & \\
$\quad$ Weak safety climate & 8 & 7.9 & 2.7 & $1.4-5.4$ \\
Use surgical mask with eye protection when cleaning up & & & & \\
large amounts of bloody diarrhea/bloody body fluid & 176 & 46.6 & & \\
$\quad$ Strong safety climate & 16 & 22.9 & 2.0 & $1.3-3.2$ \\
$\quad$ Weak safety climate & & &
\end{tabular}

CI: confidence interval, PPE: personal protective equipment. *Comparing strong with weak safety climate.

lighting; and "cluttered homes where I have to clear a space around the patient to place my medical supplies." Response options were "never," "sometimes," "usually," and "always." Consistent with previous analyses, a dichotomous summary measure was constructed that indicated whether the nurse usually/always visited homes with at least one of these characteristics. Additional analyses of these data were presented earlier ${ }^{11)}$.

\section{Safety devices}

The use of safety devices was measured by six questions that referred to the last time the nurse used a particular type of device and asked whether the device had the appropriate safety feature; for example: "The last time you used an IV catheter, did it have a shielded or a blunted stylet?" The 6 types of devices asked about were winged steel needle (was it shielded?), lancet (retracting/shielded?), syringe (sliding shield, hinged cap, or retracting needle?), IV catheter, straight needle (hinged cap/shield?), and blood tube holder (hinged cap?). Response options were "yes" and "no." Additional analyses of these data were presented previously ${ }^{17)}$.

\section{Results}

Based on the assumption that the proportion of eligible nurses from among those who did not return the questionnaire or could not be contacted was similar to the proportion among those who did return the questionnaire, the adjusted response rate was $69 \%$ ( $n=833$ eligible nurses). Participants were primarily white (91\%), female (96\%), and age $36-55$ yr $(63 \%)$.

Eighty-five percent of nurses worked for an employer that had a strong safety climate. The percentage who reported always using the specified type of PPE was $41 \%$ (wears safety goggles when irrigating a deep wound), $20 \%$ (wears a fluid-impermeable apron when providing ostomy care), and $44 \%$ (wears a surgical mask with eye protection when cleaning up large amounts of bloody diarrhea or other bloody body fluid). Fifty-five percent of nurses agreed that they have enough time (i.e., do not have to rush) during a visit; $63 \%$ usually/always visited homes with at least one of the specified adverse conditions. The percentage who used the specified safety device was $85 \%$ (winged steel needle), 76\% (lancet), 82\% (syringe), $85 \%$ (IV catheter), $70 \%$ (straight needle), and $57 \%$ (blood tube holder).

The percentage of nurses who always used the specified PPE in the indicated scenario was two to three times greater among nurses who worked in an agency with a strong safety climate compared to nurses who worked in an agency with a weak safety climate (Table 1). Among both nurses who did and did not report having to rush during visits, the percentage who used the specified PPE ( $n=4$ - 148) was greater among those who had a strong safety climate (Table 2). Similarly, among both nurses who did and did not report usually or always visiting homes with at least one adverse condition, the percentage who used the specified PPE was greater among those who had a strong safety climate (Table 3 ).

Safety climate was only weakly associated with using safety devices (Table 4). The percentage of nurses who used a device with a safety feature was 1.2 to 1.8 times greater among nurses who worked in an agency with a strong safety climate compared to those who worked in an agency with a weak safety climate. 
Table 2. Percent of nurses who always use selected items of PPE when performing the indicated procedure, by procedure, level of safety climate, and whether the nurse has to rush during home visits, North Carolina, 2006

\begin{tabular}{|c|c|c|c|c|c|c|}
\hline \multirow{2}{*}{ Procedure and safety climate } & \multicolumn{3}{|c|}{ Has to rush } & \multicolumn{3}{|c|}{ Does not have to rush } \\
\hline & $\mathrm{n}$ & $\%$ & $95 \% \mathrm{CI}^{*}$ & $\mathrm{n}$ & $\%$ & $95 \% \mathrm{CI}^{*}$ \\
\hline \multicolumn{7}{|l|}{ Use safety goggles when irrigating a deep wound } \\
\hline Strong safety climate & 84 & 37.5 & $32.8-42.2$ & 148 & 50.7 & $46.4-54.9$ \\
\hline Weak safety climate & 8 & 11.1 & $5.7-16.5$ & 7 & 25.9 & $13.7-38.2$ \\
\hline \multicolumn{7}{|c|}{ Use fluid-impermeable apron when providing ostomy care } \\
\hline Strong safety climate & 46 & 18.5 & $15.0-22.1$ & 75 & 23.8 & $20.3-27.3$ \\
\hline Weak safety climate & 4 & 5.5 & & 4 & 14.3 & \\
\hline \multirow{2}{*}{\multicolumn{7}{|c|}{$\begin{array}{l}\text { Use surgical mask with eye protection when cleaning up } \\
\text { large amounts of bloody diarrhea/bloody body fluid }\end{array}$}} \\
\hline & & & & & & \\
\hline Strong safety climate & 64 & 39.0 & $33.5-44.6$ & 112 & 52.8 & $47.8-57.8$ \\
\hline Weak safety climate & 12 & 22.6 & $14.3-31.0$ & 4 & 23.5 & \\
\hline
\end{tabular}

CI: confidence interval, PPE: personal protective equipment. Ratios were not calculated because of small numbers in several cells. *In order to be consistent with previous publications and to facilitate comparisons with them, these confidence intervals have been corrected for the finite population (i.e., all eligible nurses in North Carolina).

Table 3. Percent of nurses who always use selected items of PPE when performing the indicated procedure, by procedure, level of safety climate, and whether the nurse visits homes with adverse conditions*, North Carolina, 2006

\begin{tabular}{|c|c|c|c|c|c|c|}
\hline \multirow{2}{*}{ Procedure and safety climate } & \multicolumn{3}{|c|}{ Usually or always } & \multicolumn{3}{|c|}{ Seldom or never } \\
\hline & $\mathrm{n}$ & $\%$ & $95 \% \mathrm{CI} \dagger$ & $\mathrm{n}$ & $\%$ & $95 \% \mathrm{CI} \dagger$ \\
\hline \multicolumn{7}{|l|}{ Use safety goggles when irrigating a deep wound } \\
\hline Strong safety climate & 138 & 42.2 & $38.2-46.2$ & 94 & 49.2 & $44.0-54.5$ \\
\hline Weak safety climate & 11 & 14.9 & $8.9-20.9$ & 4 & 16.0 & \\
\hline \multicolumn{7}{|c|}{ Use fluid-impermeable apron when providing ostomy care } \\
\hline Strong safety climate & 68 & 19.2 & $16.1-22.2$ & 53 & 25.2 & $20.9-29.6$ \\
\hline Weak safety climate & 7 & 9.1 & $4.3-13.9$ & 1 & 4.2 & \\
\hline \multicolumn{7}{|c|}{$\begin{array}{l}\text { Use surgical mask with eye protection when cleaning up } \\
\text { large amounts of bloody diarrhea/bloody body fluid }\end{array}$} \\
\hline Strong safety climate & 101 & 41.9 & $37.3-46.5$ & 75 & 54.7 & $48.6-60.9$ \\
\hline Weak safety climate & 13 & 23.6 & $15.3-32.0$ & 3 & 20.0 & \\
\hline
\end{tabular}

Ratios were not calculated because of small numbers in several cells. CI: confidence interval, PPE: personal protective equipment. *Conditions counted were unrestrained pets, unruly children, poor lighting, and clutter. $\dagger$ In order to be consistent with previous publications and to facilitate comparisons with them, these confidence intervals have been corrected for the finite population.

\section{Discussion}

Although the number of respondents reporting a weak safety climate and using the selected items of PPE is small, the results of this study - that safety climate was associated with use of PPE by nurses in the home care setting - is consistent with the findings of studies among nurses in hospital settings ${ }^{9,18)}$ as well as among nonhealthcare workers ${ }^{19)}$. Thus, improving safety climate appears to be a powerful tool that management can use to increase employee use of PPE among home care/hospice nurses ${ }^{20)}$. Future research should address the factors that determine a strong safety climate and how a strong safety climate promotes use of $\mathrm{PPE}^{21-24)}$.

A strong safety climate in itself will not ensure complete use of PPE by all nurses. It has repeatedly been shown, both in populations of healthcare workers and in others, that factors other than safety climate are also important for PPE use. These include provision of PPE by the employer ${ }^{15,25-28)}$ and various aspects of organizational culture $^{29-31)}$. Improving employer compliance with safety legislation may also help ${ }^{32)}$; Scharf et al. ${ }^{33)}$ found that most home care agencies had only partially implemented the requirements of the Bloodborne Pathogen Standard ${ }^{1)}$.

The direction of causality in the association between safety climate and use of PPE can not be determined from 
Table 4. Percent of nurses who always use safety medical devices when using that type of device, by type of device and level of safety climate, North Carolina, 2006

\begin{tabular}{|c|c|c|c|c|}
\hline $\begin{array}{c}\text { Type of device and } \\
\text { level of safety climate }\end{array}$ & $\mathrm{n}$ & $\%$ & Ratio* & $95 \% \mathrm{CI}$ of ratio \\
\hline \multicolumn{5}{|l|}{ Winged steel needle } \\
\hline Strong safety climate & 578 & 88.1 & & \\
\hline Weak safety climate & 79 & 69.9 & 1.3 & $1.1-1.4$ \\
\hline \multicolumn{5}{|l|}{ Lancet } \\
\hline Strong safety climate & 474 & 78.5 & & \\
\hline Weak safety climate & 62 & 58.5 & 1.3 & $1.1-1.6$ \\
\hline \multicolumn{5}{|l|}{ Syringe } \\
\hline Strong safety climate & 552 & 84.8 & & \\
\hline Weak safety climate & 76 & 65.5 & 1.3 & $1.1-1.5$ \\
\hline \multicolumn{5}{|l|}{ IV catheter } \\
\hline Strong safety climate & 473 & 87.4 & & \\
\hline Weak safety climate & 65 & 70.7 & 1.2 & $1.1-1.4$ \\
\hline \multicolumn{5}{|l|}{ Straight needle } \\
\hline Strong safety climate & 454 & 74.2 & & \\
\hline Weak safety climate & 45 & 43.7 & 1.7 & $1.4-2.1$ \\
\hline \multicolumn{5}{|l|}{ Blood tube holder } \\
\hline Strong safety climate & 366 & 59.8 & & \\
\hline Weak safety climate & 36 & 34.0 & 1.8 & $1.3-2.3$ \\
\hline
\end{tabular}

CI: confidence interval, IV: intravenous. *Comparing strong with weak safety climate

the present study. Furthermore, from the available data we can not rule out the possibility of a spurious association caused by a tendency among respondents to answer positively (or negatively) to both the safety climate and PPE questions. Finally, the scale used to measure safety climate has not been validated, although it was derived from an instrument whose construct validity has been established ${ }^{34)}$. Future research should focus on how to improve measures of safety climate for the home care setting ${ }^{35)}$.

\section{References}

1) Occupational Safety and Health Administration Bloodborne Pathogens Standard (29 CFR 1910.1030) 2007. http:// www.osha.gov/pls/oshaweb/owadisp.show_document?p table $=$ STANDARDS\&p_id=10051. Accessed February 26, 2014.

2) National Institute for Occupational Safety and Health (2010) NIOSH Hazard review. Occupational Hazards in home healthcare. Cincinnati, OH: DHHS (NIOSH) publication no. 2010-125.

3) Occupational Safety and Health Administration Enforcement procedures for the occupational exposure to bloodborne pathogens. Directive no. CPL 02-02-069 2009. http://www.osha.gov/pls/oshaweb/owadisp.show document?p_table=DIRECTIVES\&p_id=2570\#XI. Accessed May 31, 2009.
4) Leiss JK, Lyden JT, Mathews R, Sitzman KL, Vanderpuije A, Mav D, Kendra MA, Klein C, Humphrey CJ (2009) Blood exposure incidence rates from the North Carolina study of home care and hospice nurses. Am J Ind Med 52, 99-104. [Medline] [CrossRef]

5) Gershon RR, Pogorzelska M, Qureshi KA, Sherman M (2008) Home health care registered nurses and the risk of percutaneous injuries: a pilot study. Am J Infect Control 36, 165-72. [Medline] [CrossRef]

6) Lipscomb J, Sokas R, McPhaul K, Scharf B, Barker P, Trinkoff A, Storr C (2009) Occupational blood exposure among unlicensed home care workers and home care registered nurses: are they protected? Am J Ind Med 52, 563-70. [Medline] [CrossRef]

7) Quinn MM, Markkanen PK, Galligan CJ, Kriebel D, Chalupka SM, Kim H, Gore RJ, Sama SR, Laramie AK, Davis L (2009) Sharps injuries and other blood and body fluid exposures among home health care nurses and aides. Am J Public Health 99 Suppl 3, S710-7. [Medline] [CrossRef]

8) Gershon RRM, DeJoy DM, Borwegen B, Braun B, Silverstein B, Stock L, Cullen J, Braun B (2009) Health and Safety Culture. In: State of the Sector: Healthcare and Social Assistance (DHHS (NIOSH) Publication No. 2009139): CDC/NIOSH, 87-97.

9) Gershon RR, Vlahov D, Felknor SA, Vesley D, Johnson PC, Delclos GL, Murphy LR (1995) Compliance with universal precautions among health care workers at three 
regional hospitals. Am J Infect Control 23, 225-36. [Medline] [CrossRef]

10) Rivers DL, Aday LA, Frankowski RF, Felknor S, White D, Nichols B (2003) Predictors of nurses' acceptance of an intravenous catheter safety device. Nurs Res 52, 249-55. [Medline] [CrossRef]

11) Sitzman KL, Leiss JK (2009) Documentation of incidental factors affecting the home healthcare work environment. Home Healthc Nurse 27, 516-21. [Medline] [CrossRef]

12) Leiss JK (2012) Work experience, work environment, and blood exposure among home care and hospice nurses. Ind Health 50, 521-8. [Medline] [CrossRef]

13) Murray TA (1998) From outside the walls: a qualitative study of nurses who recently changed from hospital-based practice to home health care nursing. J Contin Educ Nurs 29, 55-60. [Medline]

14) Benefield LE (1996) Making the transition to home care nursing. Am J Nurs 96, 47-9. [Medline]

15) Leiss JK, Sitzman KL, Kendra MA (2011) Provision and use of personal protective equipment among home care and hospice nurses in North Carolina. Am J Infect Control 39, 123-8. [Medline] [CrossRef]

16) Gershon RR, Karkashian CD, Grosch JW, Murphy LR, Escamilla-Cejudo A, Flanagan PA, Bernacki E, Kasting C, Martin L (2000) Hospital safety climate and its relationship with safe work practices and workplace exposure incidents. Am J Infect Control 28, 211-21. [Medline] [CrossRef]

17) Leiss JK (2010) Provision and use of safety-engineered medical devices among home care and hospice nurses in North Carolina. Am J Infect Control 38, 636-9. [Medline] [CrossRef]

18) DeJoy DM, Gershon RR, Schaffer BS (2004) Safety research-safety climate: assessing management and organizational influences on safety. Prof Saf 49, 50-7.

19) Hofmann DA, Morgeson FP, Gerras SJ (2003) Climate as a moderator of the relationship between leader-member exchange and content specific citizenship: safety climate as an exemplar. J Appl Psychol 88, 170-8. [Medline] [CrossRef]

20) Grosch JW, Gershon RR, Murphy LR, DeJoy DM (1999) Safety climate dimensions associated with occupational exposure to blood-borne pathogens in nurses. Am J Ind Med (Suppl 1): 122-4. [Medline] [CrossRef]

21) Halbesleben JR, Leroy H, Dierynck B, Simons T, Savage GT, McCaughey D, Leon MR (2013) Living up to safety values in health care: the effect of leader behavioral integrity on occupational safety. J Occup Health Psychol 18, 395-405. [Medline] [CrossRef]

22) Squires M, Tourangeau A, Spence Laschinger HK, Doran D (2010) The link between leadership and safety outcomes in hospitals. J Nurs Manag 18, 914-25. [Medline] [CrossRef]

23) Thompson DN, Hoffman LA, Sereika SM, Lorenz HL,
Wolf GA, Burns HK, Minnier TE, Ramanujam R (2011) A relational leadership perspective on unit-level safety climate. J Nurs Adm 41, 479-87. [Medline] [CrossRef]

24) Walker A (2013) Outcomes associated with breach and fulfillment of the psychological contract of safety. J Safety Res 47, 31-7. [Medline] [CrossRef]

25) Mathews R, Leiss JK, Lyden JT, Sousa S, Ratcliffe JM, Jagger J (2008) Provision and use of personal protective equipment and safety devices in the National Study to Prevent Blood Exposure in Paramedics. Am J Infect Control 36, 743-9. [Medline] [CrossRef]

26) Green-McKenzie J, Gershon RR, Karkashian C (2001) Infection control practices among correctional healthcare workers: effect of management attitudes and availabiity of protective equipment and engineering controls. Infect Control Hosp Epidemiol 22, 555-9. [Medline] [CrossRef]

27) Markkanen P, Quinn M, Galligan C, Chalupka S, Davis L, Laramie A (2007) There's no place like home: a qualitative study of the working conditions of home health care providers. J Occup Environ Med 49, 327-37. [Medline] [CrossRef]

28) Verma SK, Courtney TK, Corns HL, Huang YH, Lombardi DA, Chang WR, Brennan MJ, Perry MJ (2012) Factors associated with use of slip-resistant shoes in US limitedservice restaurant workers. Inj Prev 18, 176-81. [Medline] [CrossRef]

29) Lymer UB, Richt B, Isaksson B (2003) Health care workers' action strategies in situations that involve a risk of blood exposure. J Clin Nurs 12, 660-7. [Medline] [CrossRef]

30) Torp S, Grøgaard JB, Moen BE, Bråtveit M (2005) The impact of social and organizational factors on workers' use of personal protective equipment: a multilevel approach. J Occup Environ Med 47, 829-37. [Medline]

31) Polovich M, Clark PC (2012) Factors influencing oncology nurses' use of hazardous drug safe-handling precautions. Oncol Nurs Forum 39, E299-309. [Medline] [CrossRef]

32) Stokols D, McMahan S, Clitheroe H Jr, Wells M (2001) Enhancing corporate compliance with worksite safety and health legislation. J Safety Res 32, 441-63. [CrossRef]

33) Scharf BB, McPhaul KM, Trinkoff A, Lipscomb J (2009) Evaluation of home health care nurses' practice and their employers' policies related to bloodborne pathogens. AAOHN J 57, 275-80. [Medline] [CrossRef]

34) Anderson E, McGovern PM, Kochevar L, Vesley D, Gershon R (2000) Testing the reliability and validity of a measure of safety climate. J Healthc Qual 22, 19-24. [Medline] [CrossRef]

35) Flin R, Burns C, Mearns K, Yule S, Robertson EM (2006) Measuring safety climate in health care. Qual Saf Health Care 15, 109-15. [Medline] [CrossRef] 